\title{
Effects of grazing intensity to water source on grassland condition, yield and nutritional content of selected grass species in Northwest Ethiopia
}

\author{
Yaregal Melak', Ayana Angassa ${ }^{2^{*}}$ and Aster Abebe ${ }^{1}$
}

\begin{abstract}
Background: Savanna grasslands are globally important ecosystems consisting of one of the most extensive grazing lands with unique biodiversity. The objectives of the study were to assess the effect of grazing intensity on grassland ecosystem condition, herbaceous plant biomass production, and nutritional content of selected grass species.

Methods: The study was conducted at Chagni Ranch, Northwest Ethiopia. Four transects to water source point at regular intervals of $20 \mathrm{~m}$ between sampling plots along transects were used for data collection. The distance between the four transects was $200 \mathrm{~m}$ in radius. Data were collected on grass composition, basal cover, litter cover, number of seedlings, and age distribution of dominant grasses (i.e., young, medium, or old in terms of stage of maturity), soil condition in terms of soil compaction, and soil erosion linked to the effects of trampling by grazing animals along transects (hereafter referred to as transect) to water source point. The total sample size for grass species was 160 plots. The grassland ecosystem condition, herbaceous biomass, and grass nutritional content were used as response variables linked to transect from water source point. The effects of transect on grassland ecosystem condition scores and grass nutritional content were analyzed using the analysis of variance (ANOVA).

Results: Grassland condition factors like grass composition, basal cover, litter cover, age distribution of dominant grasses, and soil condition were significantly $(P<0.05)$ higher for the furthest transect to water source point than nearest transect. Out of the 28 identified herbaceous species, grasses accounted for $64.3 \%$ of the herbaceous community. Within grass species, about $55.6 \%$ were highly desirable in terms of palatability and grazing value (as most palatable species are susceptible to heavy grazing intensity). The results showed a significantly $(P<0.05)$ higher proportion of perennial grasses at the furthest transect to water source point than nearest transect. The dry matter yield at the furthest transect (TD4) and third transect (TD3) were significantly $(P<0.05)$ higher than the nearest transect to water source point (i.e., the first transect (TD1) and second transect (TD2)). Ash, neutral detergent fiber, acid detergent fiber, and acid detergent lignin contents of Cynodon dactylon, Sporobolus pyramidalis, and Digitaria ternata were significantly $(P<0.05)$ higher at the furthest transect to water source point than nearest transect. Grazing intensity had no significant effect on the crude protein content of Cynodon dactylon and Sporobolus pyramidalis at different transects.

(Continued on next page)
\end{abstract}

\footnotetext{
* Correspondence: ayana.angassa@gmail.com; aabdeta@buan.ac.bw

${ }^{2}$ Department of Range and Forest Resources, Faculty of Natural Resources,

Botswana University of Agriculture and Natural Resources, Private bag 0027,

Gaborone, Botswana

Full list of author information is available at the end of the article
} 
(Continued from previous page)

Conclusions: The results showed that the furthest transect to water source point were in good condition. Grass biomass production and the nutritional contents of grasses were higher for the furthest transect to water source point. The results suggested that increased grazing intensity towards water source point greatly reduced the abundance of desirable perennial grasses and the sustainability of grassland for livestock production.

Keywords: Grassland condition, Grass yield, Nutritional content, Transect

\section{Introduction}

Savanna grasslands are globally important ecosystems consisting of one of the most extensive grazing lands with unique biodiversity (Mills et al. 2006). The savannas of Africa are more explained in terms of vegetation ecology with a dominance of grasses with scattered tree life forms (Oba et al. 2000; Angassa 2007). The dynamics of vegetation in African savannas are primarily influenced by climate variability (Angassa 2007; Angassa and Oba 2008). On the other hand, grasslands are the primary sources of native forage and/or habitat for domestic ruminants and varieties of wild animals (Carlier et al. 2009). Human beings generally rely on ecosystem services for their own security (Denbeshu et al. 2018). Thus, savanna grasslands provide many of the important goods and services for human beings including food, timber, fresh water, protection from natural hazards, carbon storage, and many other functions including recreation and tourism (Messerli and Ives 1997). However, grassland ecosystems are increasingly under threat due to the impact of human activities (Denbeshu et al. 2018). Specifically, the rapid growth of human population leads to the expansion of crop cultivation into grasslands. Grazing intensity towards water point source can influence the composition of plant communities (Landsberg et al. 2002). According to Lange (1969), animal congregation and the interface between animals and water source point may lead to heavy grazing. Furthermore, climate change has the potential to alter these ecosystems and the services they provide in terms of ecosystems function and the benefits to human society.

In African, savannas are home to different species of flora and fauna (Chape et al. 2005; Newmark 2008), covering about $50 \%$ of the continent. Generally, the term savanna grassland encompasses all kinds and types of land that can be grazed by domestic and wild animals (Allen et al. 2010). Savanna grasslands are characterized by multiple functions and values (e.g., forage production for livestock) (Stypinski 2011). Savannas are rich in plant species with diverse classes of plant life forms. The high diversity of plant species as well as other living organisms is considered to be desirable characteristic in many types of grassland ecosystems that can sustain high forage production and quality for livestock production (Habtamu et al. 2013). Livestock grazing plays a major role for the maintenance of ecological diversity (Peris 2004). Grasslands cover a wide range of altitudes and those extensive grasslands are mostly found in the arid and semi-arid zones. In Ethiopia, grasslands provide the major sources of feed for the livestock sector although climate variability and recurrent droughts create forage scarcity (Reid et al. 2005; Angassa and Oba 2008).

The domestic livestock population of Ethiopia is the largest in Africa and the $10^{\text {th }}$ in the world with more than 80 million heads (Temesgen et al. 2014). Next to crop production, the livestock sector has a great potential to assist the socio-economic development and transformation of the country (Tadesse and Solomon 2014). However, the low productivity of the livestock sector is one of the biggest challenges in Ethiopia. Low livestock productivity in Ethiopia is attributed to inadequate feed supply and poor condition of the grasslands that might contribute to the low nutritional content of the native forage. Climate change is one of the major drivers altering the precipitation patterns with considerable implication on grassland ecosystem condition and forage productivity. Rainfall variability and limited moisture substantially reduce plant growth and profoundly influence the productivity of grassland and ecosystem services, livestock productivity, and human societies (Paul et al. 2015).

Livestock productivity refers to the ability of the animals grown to produce economic outputs such as livestock products and by-products of good quality (meat, milk, animal draft power, manure, hides, skins, and wool), which is largely influenced by the availability of feed resources. The major feed resources in Northwest Ethiopia are natural forage, crop residues, conserved hay from native grasses, stubble grazing, and nonconventional feeds (Solomon et al. 2014). On the other hand, the natural feed sources for livestock in northwestern part of Ethiopia are declining due to the conversion of grazing lands into cultivated lands and increased grazing intensity (Tadesse and Solomon 2014). Inadequate feed supply is one of the major constraints hampering livestock production in Ethiopia (Habtamu et al. 2013). In addition, increased grazing intensity along transect to water source point has had negative impacts on grassland condition in terms of productivity and changes in plant species composition (Galal et al. 2016). Transects to water source point can have a major influence in regulating the distribution of grazing animals in arid 
and semi-arid rangelands (Harrington 2002; Eldridge and Delgado-Baquerizo 2017). In heavily grazed areas in the nearest transect to water source point, less palatable plant species such as forbs may possibly dominate the grassland community (Angassa 2014). Bedeke and Nigatu (2015) have also shown that the density of bush encroachment is increasing in the vicinity of water source points.

Hence, knowledge of the current status of grassland ecosystem condition is relevant in terms of transect to water source point to understand the causes of change in grassland condition and nutritional content of selected grass species. The effects of grazing can cause shifts in plant species composition of the grassland ecosystems ultimately through substantial damage to soil due to the effects of trampling by grazing animals (Solomon et al. 2007; Angassa 2014). Empirical evidence on the condition of grasslands, plant biomass production, and forage quality are key factors determining the grazing capacity of savanna grasslands for sustainable livestock development. Furthermore, to improve the problem of feed scarcity and low productivity of the livestock sector, knowledge of grassland condition, species composition, and nutritional content of major grass species is essential for enhancing productivity. Previous studies (Angassa and Bars 2000; Angassa and Beyene 2003; Angassa et al. 2006; Angassa 2014) have reported the impacts of bush encroachment and altitudinal variation on grassland condition and herbaceous species composition. However, none of these studies have considered the impact of transect at various levels to water source point on grassland ecosystem condition, biomass production, shifts in vegetation composition, and nutritional content of selected grass species. Generally, empirical evidence is lacking regarding the current status of grassland ecosystem condition, biomass production, and nutritional content of selected grass species along transects to water source point in Northwest Ethiopia and, hence, this paper attempts to address these knowledge gaps.

Therefore, the objectives of the study were (1) to assess the effects of grazing intensity along transect to water source point on grassland ecosystem condition, (2) to assess the effects of grazing intensity along transect to water source point on grass biomass production, and (3) to evaluate the effects of grazing intensity along transect to water source point on the nutritional content of selected grass species.

\section{Material and methods}

\section{Study area}

The study area is located in the northwestern part of the country, approximately $505 \mathrm{~km}$ from the capital Addis Ababa (Fig. 1). Chagni Ranch is found in Guangua District of Awi Zone in Amhara National Regional State of Ethiopia. The total area of Chagni Ranch is 1367 ha. The elevation of the District is within the range of $1501-2000 \mathrm{~m}$ above sea level. The area possesses extensive areas of grassland coverage and Perennial River flows, which is suitable for livestock grazing. Livestock use different water source points along this Perennial River flows within the Ranchi grazing area. The major feed resources for livestock in the study area comprise grasses, shrubs, and tree leaves. According to Melak (2017), lack of

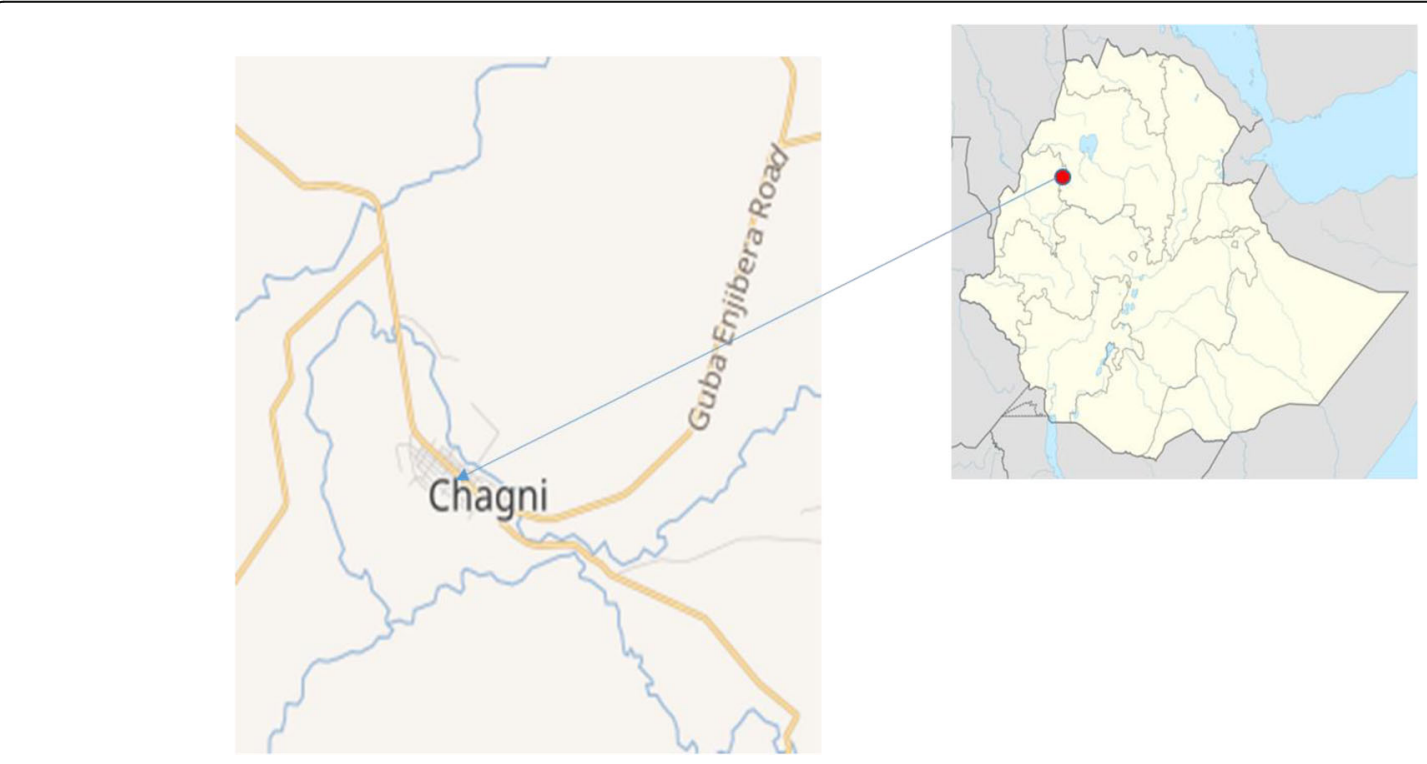

Fig. 1 Map and location of the study area in Chagni District, Northwest Ethiopia 
proper grazing management, overstocking, and/or heavy grazing are common phenomena in the study area.

The climate of the study area is classified as sub-humid, which is characterized by contrasting seasons (i.e., very wet and very dry seasons). Chagni area has a bi-modal distribution of rainfall receiving the highest amount of precipitation between May and October while the short rainy season is between February and April (Menale et al. 2011). The total population of the district is 223,066 (111,172 males and 111,894 females).

As to the vegetation of the study area, herbaceous and woody plants are the major vegetation types in the study area. Among the herbaceous species, grasses accounted for $64.3 \%$ of the total herbaceous species with $57 \%$ of the grass species being highly desirable (palatable) (Melak 2017). According to a study by Melak (2017), Cynodon dactylon, Digitaria ternata,
Digitaria velutina, Brachiaria dictyoneura, Commelina genghalensis, and Panicum maximum were the most palatable grass species. The herbaceous plants were classified into grasses, legumes, herbs and sedges. The woody vegetation of Chagni ranch is composed of trees, bushes, and shrubs. The densities of the different woody vegetation types differed from each other. Tree species like Schinus molle, Casuarina equisetifolia, and Eucaulyptus camaldulensis were found at the furthest transect to water source point. The abundances of tree species were zero to seven trees per plot (i.e., $20 \times 20$ $\mathrm{m})$. The abundances of bush plants were zero to 16 plants per plot $(10 \times 10 \mathrm{~m}$ area of plot on ranch). Historically, the vegetation of the study area was used for communal grazing areas by the local community. Since the last three decades, the ranch area was devoted primarily to the practice of ranching (i.e., the practice of raising grazing cattle for local breed improvement) run by the government under the Ministry of Agriculture.

Table 1 Experimental design of the study and plant biomass samples per block (site) in Chagni ranch, Northwest Ethiopia

\begin{tabular}{|c|c|c|c|c|c|c|c|}
\hline \multirow[t]{2}{*}{ Response variables } & \multicolumn{2}{|c|}{ Distance from water point } & \multicolumn{5}{|c|}{ Sites/block } \\
\hline & Transect & Distance & A & $B$ & C & $\mathrm{D}$ & Total \\
\hline \multirow[t]{5}{*}{ Herbaceous $(n=160)$} & TD1 & $150-330 \mathrm{~m}$ & 10 & 10 & 10 & 10 & 40 \\
\hline & TD2 & $350-530 \mathrm{~m}$ & 10 & 10 & 10 & 10 & 40 \\
\hline & TD3 & $550-730 \mathrm{~m}$ & 10 & 10 & 10 & 10 & 40 \\
\hline & TD4 & 750-930 m & 10 & 10 & 10 & 10 & 40 \\
\hline & Total & & 40 & 40 & 40 & 40 & 160 \\
\hline \multirow[t]{5}{*}{ Trees $(n=80)$} & TD1 & $150-330 m$ & 5 & 5 & 5 & 5 & 20 \\
\hline & TD2 & $350-530 \mathrm{~m}$ & 5 & 5 & 5 & 5 & 20 \\
\hline & TD3 & $550-730 \mathrm{~m}$ & 5 & 5 & 5 & 5 & 20 \\
\hline & TD4 & 750-930 m & 5 & 5 & 5 & 5 & 20 \\
\hline & Total & & 20 & 20 & 20 & 20 & 80 \\
\hline \multirow[t]{5}{*}{ Bush $(n=112)$} & TD1 & $150-330 \mathrm{~m}$ & 7 & 7 & 7 & 7 & 28 \\
\hline & TD2 & $350-530 \mathrm{~m}$ & 7 & 7 & 7 & 7 & 28 \\
\hline & TD3 & $550-730 \mathrm{~m}$ & 7 & 7 & 7 & 7 & 28 \\
\hline & TD4 & 750-930 m & 7 & 7 & 7 & 7 & 28 \\
\hline & Total & & 28 & 28 & 28 & 28 & 112 \\
\hline \multirow[t]{5}{*}{ Shrubs $(n=128)$} & TD1 & $150-330 \mathrm{~m}$ & 8 & 8 & 8 & 8 & 32 \\
\hline & TD2 & $350-530 \mathrm{~m}$ & 8 & 8 & 8 & 8 & 32 \\
\hline & TD3 & $550-730 \mathrm{~m}$ & 8 & 8 & 8 & 8 & 32 \\
\hline & TD4 & 750-930 m & 8 & 8 & 8 & 8 & 32 \\
\hline & Total & & 32 & 32 & 32 & 32 & 128 \\
\hline \multirow[t]{5}{*}{ Chemical analysis } & TD1 & $150-330 \mathrm{~m}$ & 4 & 4 & 4 & 4 & 16 \\
\hline & TD2 & $350-530 \mathrm{~m}$ & 4 & 4 & 4 & 4 & 16 \\
\hline & TD3 & 550-730m & 4 & 4 & 4 & 4 & 16 \\
\hline & TD4 & 750-930 m & 4 & 4 & 4 & 4 & 16 \\
\hline & Total & & 16 & 16 & 16 & 16 & 64 \\
\hline
\end{tabular}

TD1 transect distance 1, TD2 transect distance 2, TD3 transect distance 3, TD4 transect distance 4 


\section{Sampling design}

In order to conduct the study, Chagni ranch was divided into four blocks (Table 1). Then, four transects per each block were established radiating away from water source point. Each vegetation density and species composition was sampled in quadrats of different sizes: herb layer$1 \mathrm{~m}^{2}$, shrub layer $-25 \mathrm{~m}^{2}$, bush layer $-100 \mathrm{~m}^{2}$, and tree layer $-400 \mathrm{~m}^{2}$. Data related to the number of plots per each vegetation layer (i.e., herbaceous $=160$, shrubs $=$ 128 , bush $=112$, tree $=80$ ) and the number of plots per a single transect for each vegetation layer (i.e., herbaceous $=10$, shrubs $=8$, bush $=7$, tree $=5$ ) are presented in Table 1. Consequently, herbaceous biomass and species composition were collected from the 160 plots. The experimental design for this research is presented in Table 1 and Fig. 2. Transect 1 (TD1) was replaced $150-330 \mathrm{~m}$ distance from a water source point and hereafter referred to as the nearest transect to a water source point, transect 2 (TD2) was replaced $350-530 \mathrm{~m}$, transect 3 (TD3) was replaced $550-730 \mathrm{~m}$, and transect 4 (TD4) was replaced $750-930 \mathrm{~m}$ to a water source point, which is the furthest transect to a water source point.

\section{Grassland condition assessment}

To assess the condition of the grasslands in the study area, we used the following approach (Appendix; Baars et al. 1997). Assessments of range condition scores were based on visual estimation of percentage of decreasers or increasers at each sampling site (Appendix). According to the rangeland succession theory (Dyksterhuis 1949), grasses can be classified into desirable species, likely to decrease with heavy grazing pressure (decreasers); intermediate species, likely to increase with heavy grazing pressure (increasers); and undesirable species, likely to increase or invade with heavy grazing pressure (pioneers). The classification of grasses in the sampled plots was based on information from arid to semi-arid rangelands of southern Africa as shown in Appendix (Ivy 1969; Tainton 1981). The life forms of grasses were assessed with the help of knowledgeable farmers and manuals developed by Fromann and Persson (1974) in terms of annuals (i.e., those grasses that complete their life cycles within 1 year, and then die) and perennials (i.e., those plants that live more than 2 years). The identification of herbaceous plant species was carried out according to the guidelines developed by Fromann

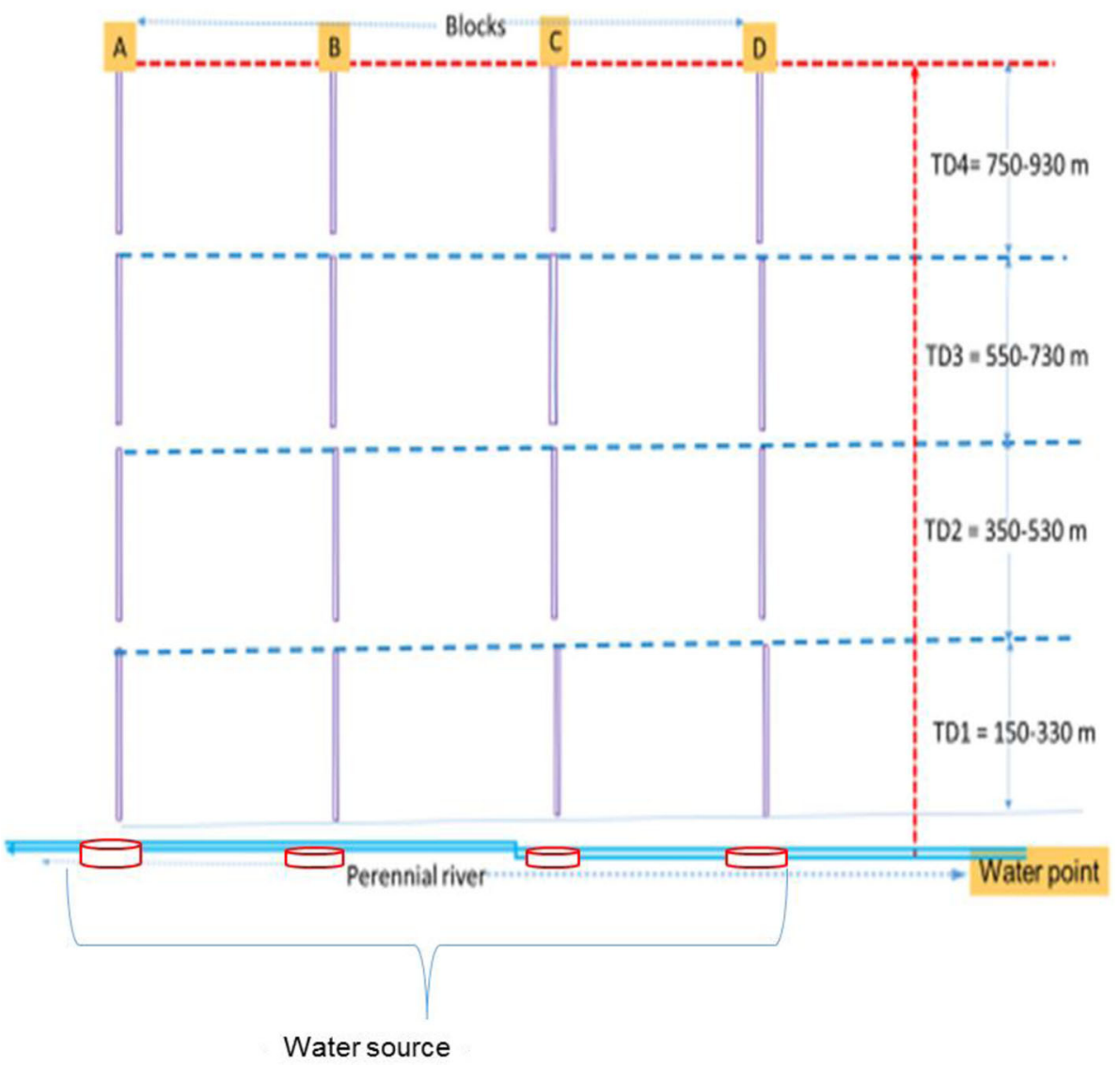

Fig. 2 Schematic representation of the sampling design for transect radiating from water source point 
and Persson (1974), and by comparison with specimens stored in the national Herbarium Addis Ababa. These were augmented by the opinions of local elders on the palatability of a particular species. Information was gathered from community representatives and key informants (livestock keepers) on vigor and palatability of a particular species. A species with high palatability was considered a decreaser, whereas a species with medium palatability that is not affected by grazing pressure was considered an increaser. Scores were based on visual estimation of percentage of decreasers or increasers at each sampling site (Appendix).

A maximum score of 10 points each was given for three of the factors (grass composition, basal cover, and litter cover) and a maximum score of 5 points each for the remaining four factors (number of seedlings, size distribution of selected grass species, soil erosion, and soil compaction), summing to a maximum possible score of 50 points. Hence, five levels of total scores were used and these were interpreted as follows: very poor $(\leq 10$ score), poor (11-20 score), fair (21-30 score), good (3140 score), and excellent (41-50 score). Then, to assess the condition of grasslands, we measured the following factors in the field: grass composition (0-10 score), basal cover (0-10 score), and litter cover (010 score) (Appendix). Basal cover refers to the proportion of the plant that extends into the soil, and we measure both the green and dead plants from the same year. On the other hand, the detached and dead fallen parts of the plants were considered to be litter. A representative area of $1 \mathrm{~m}^{2}$ was selected at each sampling site for detailed assessments, and the $1 \mathrm{~m}^{2}$ plot was divided into two halves. One half was further divided into quarters, one of which was divided into eighths. All plant basal cover in the selected 1 $\mathrm{m}^{2}$ was uprooted, transferred while kept together, and drawn in the eighth segment to facilitate visual estimations of basal cover of living parts. We assigned the basal plant cover a score based on the relative plant cover of living plants in the field as follows: 0 score for $0 \%, 1$ for $<1 \%, 2$ for $1-3 \%, 3$ for $>3 \%$ composed mainly of annuals, 4 for $>3 \%$ mainly perennials, 5 for $>6 \%$ with bare spots, 6 for $>6 \%$ and evenly distributed, 7 for $>9 \%$ with occasional bare spots, 8 for $>9 \%$ and evenly distributed, 9 for $>12 \%$ with slightly bare spots, and 10 for $>12 \%$ with no bare spots. Similarly, we assigned the litter plant cover a score based on the relative dead and fallen plant parts in the field as follows: 0 score for $<3 \%, 2$ for $3-10 \%$ with weeds or tree leaves, 4 for $3-10 \%$ composed mainly of grasses, 6 for $11-40 \%$ and unevenly distributed, 8 for $11-40 \%$ and evenly distributed, and 10 for $>40 \%$ (Baars et al. 1997). The rating for basal cover of tufted species was considered "excellent" when the eighth was completely filled (i.e., $12.5 \%)$ and "very poor" when the cover was less than $3 \%$. The rating for litter cover within the same area of $1 \mathrm{~m}^{2}$ was considered "excellent" when the litter cover exceeded $40 \%$ and "poor" when less than $10 \%$ was covered by litter (Appendix).

\section{Number of seedlings ( $0-5$ score)}

The number of seedlings at each sampling site was counted using three areas, $10 \mathrm{~m}$ apart, equal to the size of an A4 sheet of paper $(30 \times 21 \mathrm{~cm})$ chosen at random. The sheet was dropped from a height of $2 \mathrm{~m}$ above the ground. We assigned the basal plant cover a score based on the relative plant cover of living plants in the field as follows: 0 score for no seedlings in the area outlined by the A4 paper, 1 for one seedling, 2 for two seedlings, 3 for three seedlings, 4 for four seedlings, and 5 for greater than four seedlings (Appendix).

\section{Size distribution (1-5 score)}

Size distribution, which was considered to reflect the stage of maturity of the grass plants, was based on visual observation and estimation of the size of the grass tussocks (i.e., small area of grass that is thicker or longer than the grass growing around it) within the $100 \mathrm{~m}$ radius in a circular form surrounded by researchers and observers for this purpose. The presence of small, medium and large grass plants of the dominant species was considered as all size categories, Small- and medium-sized plants were defined as having approximately $20 \%$ and $50 \%$, respectively, of the size of large mature grass plants of the dominant species. We assigned the size categories of dominant grass species as follows: 5 score for the presence of all size categories of grasses, 4 score for the presence of small- and medium-sized groups, 3 score only for the presence of large-sized group, 2 score only for the presence of medium-sized groups of grass plants, and 1 score for the presence of small-sized grass plants (Appendix).

\section{Soil erosion (0-5 score) and soil compaction (1-5 score)}

Soil erosion assessment was based on the amount of pedestals (higher part of soils, held together by plant roots, with eroded soil around the tuft), and in severe cases, the presence of pavements (terraces of flat soil, normally without basal cover, with a line of tufts between pavements) (Appendix). If there was no sign of soil erosion (no soil movement), a maximum score of 5 was given and a minimum score of 0 was given in situations where gully formation was observed due to soil erosion. The occurrence of slight sand mulch, slope-sided pedestals, steep-sided pedestals, and 
pavements coincided with scores of $4,3,2$, and 1, respectively. Soil compaction was based on the amount of capping (crust formation). If there was no compaction, a maximum score of 5 was given and the scores decreased with increasing capping of the soil. Scores of $4,3,2$, and 1 were given for soils with isolated capping, $>50 \%$ capping, $>75 \%$ capping, and almost $100 \%$ capping, respectively (Appendix).

\section{Chemical analysis}

Selected grass species samples were oven dried at $105^{\circ} \mathrm{C}$ for $24 \mathrm{~h}$ to determine the dry weight of the samples. The nitrogen $(\mathrm{N})$ content was analyzed using the micro-Kjeldhal procedure and the crude protein (\%CP) was calculated as $N \times 6.25$. The neutral detergent fiber (\%NDF), acid detergent fiber (\%ADF), and acid detergent lignin (\%ADL) were determined according to the method described by Van Soest and Robertson (1985).

\section{Data analysis}

Grass composition (GC), basal cover (BC), litter cover (LC), age distribution of dominant grasses (AD) based on three age categories (young, medium age, and old grasses), numbers of grass seedlings (NS), soil conditions (SC) in terms of effect of erosion and compaction due to trampling effect from livestock grazing, and herbaceous species biomass were considered as numerical response variables against the transect to water source point. The data were checked for normality. Then, analysis of variance (ANOVA) was carried out to analyze the data using the general linear models (GLM) procedure of Statistical Package for Social Sciences (SPSS version 16.0) program. The model included sites/blocks and transect to water source point in a $4 \times 4$ factorial arrangement. Post-hoc test was employed to compare the mean differences. Statistical significance was set at $P \leq 0.05$.

\section{Results}

\section{Effects of grazing intensity on range condition}

The effect of grazing intensity along transect to water source point on range condition parameters is presented in Table 2. The range condition scores for grass composition $(\mathrm{GC})$ at the furthest transect (TD4 and TD3) to a water source point were significantly $(P<0.05)$ higher than the range condition scores for the nearest transect (TD1 and TD2). Generally, the nearest transect (TD1) had low grass species composition as compared to the rest three transects to a water source point. Grass basal cover (BC) had a significantly $(P<0.05)$ higher range condition score at the furthest transect (TD4) to a water source point
Table 2 Effects of grazing intensity on range condition scores from water source point in Chagni ranch, Northwest Ethiopia

\begin{tabular}{lllllllll}
\hline Parameters & \multicolumn{6}{c}{ Effect of grazing intensity on range condition scores } \\
\cline { 2 - 9 } & TD1 & TD2 & TD3 & TD4 & SE & DF & F value & $P$ value \\
\hline GC & $5.92^{\mathrm{b}}$ & $6.13^{\mathrm{b}}$ & $6.80^{\mathrm{a}}$ & $6.78^{\mathrm{a}}$ & 0.17 & 3 & 7.01 & 0.00 \\
BC & $5.48^{\mathrm{c}}$ & $6.12^{\mathrm{b}}$ & $6.38^{\mathrm{ab}}$ & $6.78^{\mathrm{a}}$ & 0.17 & 3 & 10.54 & 0.00 \\
LC & $3.20^{\mathrm{b}}$ & $3.95^{\mathrm{a}}$ & $4.03^{\mathrm{a}}$ & $4.28^{\mathrm{a}}$ & 0.17 & 3 & 7.74 & 0.00 \\
AD & $3.10^{\mathrm{b}}$ & $3.48^{\mathrm{b}}$ & $4.05^{\mathrm{a}}$ & $4.02^{\mathrm{a}}$ & 0.13 & 3 & 11.81 & 0.00 \\
NS & 2.38 & 2.38 & 2.60 & 2.40 & 0.14 & 3 & 0.595 & 0.619 \\
SE & $3.28^{\mathrm{d}}$ & $3.78^{\mathrm{c}}$ & $4.32^{\mathrm{b}}$ & $4.68^{\mathrm{a}}$ & 0.10 & 3 & 34.89 & 0.00 \\
SC & $2.80^{\mathrm{c}}$ & $3.18^{\mathrm{b}}$ & $3.30^{\mathrm{b}}$ & $3.80^{\mathrm{a}}$ & 0.10 & 3 & 17.44 & 0.00 \\
Total & $26.16^{\mathrm{c}}$ & $29.02^{\mathrm{b}}$ & $31.47^{\mathrm{a}}$ & $32.74^{\mathrm{a}}$ & 0.47 & 3 & 38.65 & 0.00 \\
\hline
\end{tabular}

$a, b, c, d$ Means with different superscripts for each parameter within the same row were significantly different $(P<0.05)$

TD1 transect distance 1, TD2 transect distance 2, TD3 transect distance 3, TD4 transect distance $4, G C$ grass composition, $B C$ basal cover, $L C$ litter cover, $A D$ age distribution, NS number of seedlings, SE soil erosion, and SC soil compaction

than at the other three transects (i.e., TD1, TD2, and TD3) (Table 2). For example, BC had on average 1 score more in TD3 and TD4 than in TD1. The nearest transect (TD1) to a water source point had a significantly $(P<0.05)$ lower litter cover $(\mathrm{LC})$ score than the other three transects (i.e., TD2, TD3, and TD4). Overall, higher range condition score values were recorded for grass composition, basal cover, litter cover, and age distribution of dominant grasses at the furthest transect (TD3 and TD4) to a water source point than the nearest transect (TD1 and TD2). The range condition score for the number of seedlings did not show any significant $(P>0.05)$ difference among the four transects to a water source point. The range condition score for soil erosion was significantly $(P<$ 0.05) higher for the nearest transect (TD1), i.e., with the lowest score of range condition. SE had on average 1.4 score more in TD3 and TD4 than in TD1 with increased soil erosion in TD1 (i.e., nearest to water source point). Soil erosion and compaction were significantly $(P<0.05)$ higher for the nearest transect (TD1) to water source point than those for the second transect (TD2). The results for soil erosion and compaction also showed a significantly $(P<$ 0.05) higher range condition score for TD2 than those for TD3 and TD4. The present results showed a significantly $(P<0.05)$ higher range condition score for TD1 in terms of soil compaction. The overall range condition scores for TD1 (26.16) and TD2 (29.02) were in fair conditions. The overall range condition scores for TD3 (31.47) and TD4 (32.74) were in good conditions, and these results were significantly $(P<0.05)$ higher than the scores for TD1 and TD2. 
Table 3 Effects of grazing intensity on life forms, desirability and dry weight $\left(\mathrm{g} / \mathrm{m}^{2}\right)$ of different herbaceous species in Chagni Ranch, Northwest Ethiopia

\begin{tabular}{|c|c|c|c|c|c|c|}
\hline \multirow[t]{2}{*}{ Species } & \multirow[t]{2}{*}{ Life forms } & \multirow[t]{2}{*}{ desirability } & \multicolumn{4}{|c|}{ Dry weight of plant biomass $\left(\mathrm{g} / \mathrm{m}^{2}\right)$} \\
\hline & & & TD1 & TD2 & TD3 & TD4 \\
\hline \multicolumn{7}{|l|}{ Grasses } \\
\hline Cynodon dactylon & Perennial & Highly desirable & 0.77 & 0.87 & 0.97 & 1.06 \\
\hline Chloris pycnothrix & Annual & Moderately desirable & 0.45 & 0.45 & 0.45 & 0.47 \\
\hline Aristida congesta & Perennial & Less desirable & 0.45 & 0.45 & 0.45 & 0.45 \\
\hline Digitaria ternata & Annual & Highly desirable & 0.45 & 0.47 & 0.50 & 0.51 \\
\hline Digitaria velutina & Annual & Highly desirable & 0.45 & 0.46 & 0.46 & 0.48 \\
\hline Eragrostis cilianens & Annual & Moderately desirable & 0.45 & 0.46 & 0.46 & 0.48 \\
\hline Brachiaria dictyoneura & Perennial & Highly desirable & 0.45 & 0.46 & 0.46 & 0.46 \\
\hline Brachiaria spp. & Annual & Highly desirable & 0.47 & 0.52 & 0.49 & 0.54 \\
\hline Eleusine indica & Annual & Less desirable & 0.47 & 0.49 & 0.45 & 0.45 \\
\hline Setaria verticillata & Annual & Moderately desirable & 0.46 & 0.47 & 0.46 & 0.49 \\
\hline Commelina genghalensis & Perennial & Highly desirable & 0.45 & 0.45 & 0.45 & 0.45 \\
\hline Panicum maximum & Perennial & Highly desirable & 0.45 & 0.47 & 0.49 & 0.48 \\
\hline Panicum coloratum & Perennial & Highly desirable & 0.45 & 0.45 & 0.48 & 0.47 \\
\hline Hyparrhenia hirta & Perennial & Less desirable & 0.51 & 0.48 & 0.48 & 0.48 \\
\hline Paspalum orbiculate & Perennial & Highly desirable & 0.47 & 0.50 & 0.53 & 0.45 \\
\hline Sporobolus pyramidalis & Perennial & Less desirable & 0.67 & 0.61 & 0.58 & 0.56 \\
\hline Pennisetum purpureum & Perennial & Moderately desirable & 0.45 & 0.46 & 0.46 & 0.45 \\
\hline Chloris gayana & Perennial & Highly desirable & 0.48 & 0.48 & 0.49 & 0.51 \\
\hline \multicolumn{7}{|l|}{ Legumes } \\
\hline Tephrosia vugelii & Perennial & Highly desirable & 0.45 & 0.45 & 0.45 & 0.45 \\
\hline Trifolium rueppellianum & Annual & Highly desirable & 1.10 & 1.12 & 0.98 & 0.92 \\
\hline Crotalaria spinosa & Perennial & Less desirable & 0.47 & 0.47 & 0.45 & 0.45 \\
\hline Achyranthes aspera & Perennial & Less desirable & 0.68 & 0.67 & 0.68 & 0.61 \\
\hline Desmodium uncinatum & Annual & Highly desirable & 0.47 & 0.45 & 0.45 & 0.50 \\
\hline \multicolumn{7}{|l|}{ Forbs } \\
\hline Bidens pilosa & Annual & Less desirable & 0.62 & 0.57 & 0.59 & 0.49 \\
\hline Guizotia scabra & Annual & Less desirable & 0.60 & 0.47 & 0.49 & 0.46 \\
\hline Amaranthus spinosus & Annual & Moderately desirable & 0.45 & 0.53 & 0.45 & 0.45 \\
\hline Ocimum suave & Perennial & Highly desirable & 0.45 & 0.47 & 0.52 & 0.51 \\
\hline \multicolumn{7}{|l|}{ Sedge } \\
\hline Cyperus esculentus & Perennial & Moderately desirable & 0.45 & 0.45 & 0.39 & 0.34 \\
\hline
\end{tabular}

TD1 transect distance 1, TD2 transect distance 2, TD3 transect distance 3, TD4 transect distance 4

Table 4 Effects of grazing intensity on mean dry biomass weight of herbaceous species in Chagni ranch, Northwest Ethiopia

\begin{tabular}{|c|c|c|c|c|c|c|c|c|}
\hline \multirow[t]{2}{*}{ Parameters } & \multicolumn{8}{|c|}{ Mean dry biomass weight $\left(\mathrm{g} / \mathrm{m}^{2}\right)$} \\
\hline & TD1 & TD2 & TD3 & TD4 & SE & DF & F-value & $P$ value \\
\hline Highly desirable & $71.22^{b}$ & $74.64^{b}$ & $85.26^{\mathrm{a}}$ & $86.8^{\mathrm{a}}$ & 0.85 & 3 & 20.33 & 0.000 \\
\hline Moderately desirable & 29.33 & 29.83 & 34.1 & 35.34 & 1.38 & 3 & 1.2 & 0.365 \\
\hline Less desirable & $40.87^{b}$ & $41.71^{b}$ & $46.28^{\mathrm{ab}}$ & $47.39^{\mathrm{a}}$ & 0.67 & 3 & 5.86 & 0.017 \\
\hline Mean dry biomass & $141.43^{b}$ & $146.15^{\mathrm{b}}$ & $165.57^{\mathrm{a}}$ & $169.54^{\mathrm{a}}$ & 2.49 & 3 & 7.85 & 0.007 \\
\hline
\end{tabular}

a,b Means with different superscripts for each parameter within the same row were significantly different $(P<0.05)$

TD1 transect distance 1,TD2 transect distance 2, TD3 transect distance 3, TD4 transect distance 4 


\section{Effects of grazing intensity on grass yield}

The total dry matter (biomass) production of all herbaceous samples and that of grasses were significantly $(P<0.05)$ higher for TD3 and TD4 (Table 3). Similarly, the DM of highly desirable grass species for TD3 and TD4 were significantly $(P<0.05)$ higher than those for TD1 and TD2. The DM production of desirable legume species for TD1 was the lowest (Table 3). There were significant differences $(P<0.05)$ among the different transects in terms of the less desirable legume species (Table 4). There were also significance differences $(P<$ $0.05)$ among all transects in terms of desirable herb species (Table 4). The total biomass production of herbaceous species was increased from 141.43 to $169.54 \mathrm{~g} \mathrm{~m}^{-2}$ as the range condition was increased from fair condition in the nearest transect to a good condition at the furthest transect to a water source point with reduced grazing intensity (Table 4).
Effects of grazing intensity on nutritional content of grasses The total dry matter production of herbaceous samples were significantly $(P<0.05)$ higher for TD3 and TD4. Dry matter is a measurement of the aboveground biomass of grass samples after completely oven dried at a constant temperature under laboratory condition (Van Soest and Robertson 1985). Similarly, the DM content of four major grass species such as Cynodon dactylon, Sporobolus pyramidalis, Setaria verticillata, and Digitaria ternata were significantly $(P<0.05)$ higher for the furthest transects (TD3 and TD4) than those for the nearest transects (TD1 and TD2) to water source point (Table 5). The ash content of major grass species in the study area was also significantly $(P<0.05)$ higher for the furthest transects (TD3 and TD4) than that in the nearest transects (TD1 and TD2) to a water source point (Table 5). The proportion of NDF, ADF, and ADL in grasses were significantly $(P<0.05)$ higher for the furthest transects (TD3 and TD4) than

Table 5 Effects of grazing intensity on chemical compositions of major grass species in Chagni ranch, Northwest Ethiopia

\begin{tabular}{|c|c|c|c|c|c|c|c|c|c|}
\hline \multirow[t]{2}{*}{ Species } & \multirow[t]{2}{*}{ Parameters } & \multicolumn{8}{|c|}{ Distances from water points } \\
\hline & & $\mathrm{TD1}$ & TD2 & TD3 & TD4 & SE & DF & F-value & $P$ value \\
\hline \multirow[t]{6}{*}{ Cynodon dactylon } & $D M \%$ & $87.92^{b}$ & $88.46^{\mathrm{b}}$ & $91^{a}$ & $92.04^{\mathrm{a}}$ & 0.15 & 3 & 43.62 & 0.00 \\
\hline & Ash & $8.02^{c}$ & $8.78^{b c}$ & $9.75^{\mathrm{ab}}$ & $10.9^{\mathrm{a}}$ & 0.408 & 3 & 9.314 & 0.004 \\
\hline & NDF & $54.32^{c}$ & $54.55^{c}$ & $57.96^{b}$ & $59.39^{\mathrm{a}}$ & 0.334 & 3 & 56.85 & 0.00 \\
\hline & ADF & $33.3^{b}$ & $33.7^{\mathrm{b}}$ & $37.11^{\mathrm{a}}$ & $38.54^{\mathrm{a}}$ & 0.902 & 3 & 8.124 & 0.006 \\
\hline & $A D L$ & $4.96^{\mathrm{b}}$ & $5.22^{\mathrm{b}}$ & $6.27^{\mathrm{a}}$ & $6.66^{\mathrm{a}}$ & 0.12 & 3 & 46.48 & 0.00 \\
\hline & $C P$ & 9.1 & 8.71 & 8.82 & 8.67 & 0.23 & 3 & 0.176 & 0.91 \\
\hline \multirow[t]{6}{*}{ Sporobolus pyramidalis } & $\mathrm{DM} \%$ & $88.78^{b}$ & $89.48^{b}$ & $90.96^{\mathrm{ab}}$ & $92.38^{\mathrm{a}}$ & 0.27 & 3 & 9.03 & 0.004 \\
\hline & Ash & $7.44^{b}$ & $7.7^{b}$ & $8.8^{\mathrm{a}}$ & $9.4^{\mathrm{a}}$ & 0.365 & 3 & 6.313 & 0.014 \\
\hline & NDF & $54.3^{c}$ & $54.5^{c}$ & $57.9^{b}$ & $59.4^{\mathrm{a}}$ & 0.237 & 3 & 30.62 & 0.00 \\
\hline & ADF & $36.14^{b}$ & $36.3^{b}$ & $37.6^{\mathrm{b}}$ & $39.7^{\mathrm{a}}$ & 0.54 & 3 & 9.38 & 0.004 \\
\hline & $\mathrm{ADL}$ & 6.9 & 7.4 & 7.8 & 7.8 & 0.264 & 3 & 2.317 & 0.144 \\
\hline & $C P$ & 7.93 & 7.54 & 7.4 & 7.38 & 0.15 & 3 & 0.71 & 0.57 \\
\hline \multirow[t]{6}{*}{ Setaria verticillata } & $\mathrm{DM} \%$ & $88.51^{c}$ & $90.21^{b}$ & $90.41^{b}$ & $92.45^{\mathrm{a}}$ & 0.172 & 3 & 22.11 & 0.00 \\
\hline & Ash & $6.62^{b}$ & $6.71^{b}$ & $8.55^{\mathrm{a}}$ & $9.57^{\mathrm{a}}$ & 0.33 & 3 & 19.25 & 0.00 \\
\hline & NDF & $55.9^{c}$ & $56.9^{b c}$ & $58.9^{\mathrm{ab}}$ & $60.6^{\mathrm{a}}$ & 0.523 & 3 & 15.97 & 0.001 \\
\hline & ADF & $36.13^{c}$ & $38.2^{\mathrm{bc}}$ & $39.5^{\mathrm{ab}}$ & $41.6^{\mathrm{a}}$ & 0.589 & 3 & 15.2 & 0.001 \\
\hline & $\mathrm{ADL}$ & $5.19^{c}$ & $5.33^{c}$ & $6.22^{\mathrm{b}}$ & $6.73^{\mathrm{a}}$ & 0.084 & & 76.72 & 0.00 \\
\hline & $\mathrm{CP}$ & $8.08^{\mathrm{a}}$ & $7.78^{\mathrm{ab}}$ & $7.25^{\mathrm{b}}$ & $7.22^{\mathrm{b}}$ & 0.07 & 3 & 8.776 & 0.005 \\
\hline \multirow[t]{6}{*}{ Digitaria ternata } & $\mathrm{DM} \%$ & $87.03^{c}$ & $88.81^{b}$ & $92.38^{\mathrm{a}}$ & $92.93^{\mathrm{a}}$ & 0.133 & 3 & 114.1 & 0.00 \\
\hline & Ash & $9.25^{c}$ & $9.92^{\mathrm{b}}$ & $10.5^{\mathrm{ab}}$ & $11.2^{\mathrm{a}}$ & 0.294 & 3 & 7.745 & 0.007 \\
\hline & NDF & $45.24^{b}$ & $46.6^{b}$ & $48.9^{\mathrm{a}}$ & $50^{a}$ & 0.576 & 3 & 14.13 & 0.001 \\
\hline & $\mathrm{ADF}$ & $32.9^{b}$ & $34.7^{\mathrm{ab}}$ & $36.1^{\mathrm{ab}}$ & $37.7^{\mathrm{a}}$ & 0.849 & 3 & 5.866 & 0.017 \\
\hline & ADL & $5.5^{\mathrm{b}}$ & $5.54^{\mathrm{b}}$ & $6.68^{\mathrm{a}}$ & $7.1^{\mathrm{a}}$ & 0.116 & 3 & 47.31 & 0.00 \\
\hline & $C P$ & $9.99^{\mathrm{a}}$ & $9.41^{b}$ & $8.94^{b}$ & $8.86^{b}$ & 0.071 & 3 & 13.15 & 0.001 \\
\hline
\end{tabular}

$\overline{a, b, c}$ Means in the same row for each parameter with different superscripts were significantly different $(P<0.05)$

$T D 1$ transect distance 1, TD2 transect distance 2, TD3 transect distance 3, TD4 transect distance 4, DM dry matter, NDF neutral detergent fiber, $A D F$ acid detergent fiber, $A D L$ acid detergent lignin, and $C P$ crude protein 
those for the nearest transects to water source point. However, Sporobolus pyramidalis was exceptional in terms of ADL where it did not show any significant difference $(P>0.05)$ among the different transects. The percentage of crude protein $(\mathrm{CP})$ in Cynodon dactylon and Sporobolus pyramidalis did not show any significant $(P>0.05)$ difference among all the four transects in the study area. However, the $\mathrm{CP}$ content of Setaria verticillata and Digitaria ternata was significantly $(P<0.05)$ lower for the furthest transect (TD4) than the nearest transect (TD1) to water source point (Table 5).

\section{Discussion}

\section{Effects of grazing intensity on range condition}

From the results, key findings emerge in terms of increased grazing intensity towards water source point that might have had a considerable effect on grass basal cover, litter cover, and grass community composition. This suggests that grazing intensity can directly or indirectly contribute to the reduction in the proportion of desirable (highly palatable) grass species while increasing the proportion of grazing-tolerant species (increasers and invaders). We showed that the most palatable grass species (i.e., decreasers) are declining from the plant community composition due to the impact of grazing intensity nearest to a water source point. Our findings link well with previous studies (Solomon et al. 2007; Shahriary et al. 2012; Angassa 2014) wherein grass species composition was affected considerably by livestock grazing in southern Ethiopia and elsewhere (Landsberg et al. 2002) along transects to water source point. Another promising finding was that grazing intensity negatively affected the age/size distribution of dominant grasses along transects to water source points. This implies that grassland sites nearest to a water source point are associated with high concentration of livestock grazing and subsequent trampling that could cause considerable damage on the age class distribution of grasses. Others (Landsberg et al. 2002; Angassa et al. 2010; Angassa 2014) have shown that increased grazing intensity and trampling effect in the vicinity of water source point can affect soil stability and vegetation condition, often leading to substantial reductions in ecosystem services and functions. A similar conclusion was reached by previous studies (Shahriary et al. 2012; Eldridge and Whitford 2009), suggesting that more soil disturbance can occur due to the effects of trampling and year-round grazing in the vicinity of water source point.

\section{Effects of grazing intensity on grass yield}

The furthest grassland sites (TD4) to water source point accumulate more biomass production of herbaceous vegetation than the nearest grassland sites (TD2 and TD1). This is important because heavy grazing intensity and soil disturbance in the vicinity of water source point can cause greater damage on herbaceous plant communities and reduction in yield. It is interesting to note that annual plants dominate grassland sites nearest to a water source point, whereas the distribution and abundance of annual plants decrease with reduced grazing intensity at the furthest transect to a water source point. Similarly, Canan et al. (2011) have reported a significant change in the botanical composition of vegetation in the vicinity of water source point with increased grazing intensity. Overall, most of the herbaceous species listed in Table 3 produced less than 1 $\mathrm{g} / \mathrm{m}^{2}$ most likely due to the influence of year-round grazing in the studied ranch area. The findings indicate that the herbaceous biomass production around water source point in Chagni ranch is very low perhaps due to the high concentration of livestock and frequent grazing nearest to a water source point. According to Abate et al. (2012), heavy grazing intensity leads to grassland deterioration and reduction in biomass production. The total dry matter production for the nearby transect to a water source point is significantly lower with fair grassland condition. In contrast, the furthest transects to a water source point were in good grassland condition with more biomass production. This is in line with the reports by others (Mengistu et al. 2015; Solomon et al. 2007; Todd 2006), suggesting that heavy and continuous grazing can cause a reduction in herbaceous biomass. The current findings are also supported by others results (Asheber et al. 2010; Todd 2006; Martin 2006), suggesting that annual herbs and less desirable herbaceous species can tolerate heavy grazing and disturbances nearest to water source point, while desirable grass species dominant at the furthest grassland sites to water source point.

Effects of grazing intensity on nutritional contents of grasses The nutritional contents of four selected grass species were analyzed (Table 5). The furthest transects (TD3 and TD4) to water source point produced more accumulation of total dry matter production of herbaceous plants than the nearest transects. We speculate that this might be due to the effect of increased grazing intensity (Angassa et al. 2010; Emmanuel et al. 2012) in the vicinity of water source points. Similarly, the DM production of four selected grass species, namely Cynodon dactylon, Sporobolus pyramidalis, Setaria verticillata, and Digitaria ternata were significantly higher at the furthest transects to a water source point than the nearest transects. This might be due to differences in the intensity of grazing along a transect to a water source point. The low ash composition of major grass species in the 
nearest transects (TD1 and TD2) to a water source point might suggest excessive deterioration of grassland condition and susceptibility of the soil to erosion. Our results demonstrate that the proportions of NDF, ADF, and ADL in the study area were higher at the furthest transects to a water source point than those at the nearest transects. This is most likely as a result of more accumulation of old and mature grasses in areas of low grazing intensity, i.e., at the furthest transects to a water source point (Allen et al. 2006). Generally, the furthest transects to a water source point are under low grazing intensity as compared to the nearest transects, which enhances more accumulation of fiber contents (NDF, ADF, and ADL) with old and underutilized forage plants. The current findings are consistent with the findings of Habtamu et al. (2013) who suggest that the fiber constituents of herbaceous forage species increase as the stage of maturity of the forage plant advances. One promising finding was that the crude protein content of Cynodon dactylon and Sporobolus pyramidalis did not show any significant differences among transects in the present study. This might be due to the effect of continuous grazing where the rejuvenation of new grasses at the nearest transect contributes to high crude protein content (Bilatu et al. 2013; Abdel et al. 2013). A similar study by Mengistu et al. (2015) indicates that herbaceous species in the open-grazed areas have high crude protein content than those in the rangeland areas that are protected from moderate grazing.

\section{Conclusion}

We assessed the effects of grazing intensity along transects to water source point on grassland ecosystem condition, grass biomass, and nutritional content of selected grass species. The analysis leads to the conclusion that the furthest transects to water source point were in good condition, whereas the nearest transects to water source point were in fair condition. As we argued elsewhere, increased grazing intensity towards water source point may be considered a major factor affecting desirable perennial grasses and sustainable livestock production. Nevertheless, we found more accumulation of herbaceous annuals in the vicinity of water source point with increased grazing intensity. Overall, our results demonstrate a strong influence of grazing intensity on dry matter production of herbaceous plants. We have shown that grazing intensity strongly influenced the nutritional contents (NDF, ADF, and ADL) of selected grass species with the exception of Sporobolus pyramidalis. Our results suggest that grazing intensity to water source point did not have any significant effect on the proportions (\%) of $\mathrm{CP}$ of Cynodon dactylon and Sporobolus pyramidalis. However, grazing intensity to water source point had a significant effect on \%CP of Setaria verticillata and Digitaria ternata that might strongly influence livestock productivity. We suggest that future research should consider the potential effects of grazing intensity on plant species composition more carefully and its influence on sustainable livestock production.

\section{Appendix}

Table 6 Range condition scoring rate according to Baars et al. (1997)

\begin{tabular}{|c|c|c|c|c|c|c|c|}
\hline GC & $\mathrm{BC}$ & LC & NS & $A D$ & SC & SE & Score \\
\hline $91-100 \%$ decreasers & $\begin{array}{l}>12 \% \text { no bare } \\
\text { spot }\end{array}$ & $>40 \%$ & & & & & 10 \\
\hline $81-90 \%$ decreasers & $\begin{array}{l}>12 \% \text { slightly } \\
\text { bare spots }\end{array}$ & & & & & & 9 \\
\hline $71-80 \%$ decreasers & $\begin{array}{l}>9 \% \text { evenly } \\
\text { distributed }\end{array}$ & $\begin{array}{l}11-40 \% \text { and evenly } \\
\text { distributed }\end{array}$ & & & & & 8 \\
\hline $61-70 \%$ decreasers & $\begin{array}{l}>9 \% \text { occasional } \\
\text { bare spots }\end{array}$ & & & & & & 7 \\
\hline $51-60 \%$ decreasers & $\begin{array}{l}>6 \% \text { evenly } \\
\text { distributed }\end{array}$ & $\begin{array}{l}11-40 \% \text { and unevenly } \\
\text { distributed }\end{array}$ & & & & & 6 \\
\hline $41-50 \%$ decreasers & $\begin{array}{l}>6 \% \text { bare } \\
\text { spots }\end{array}$ & & $\begin{array}{l}>4 \\
\text { seedlings }\end{array}$ & All age categories & No sign of erosion & $\begin{array}{l}\text { No sign of } \\
\text { compaction }\end{array}$ & 5 \\
\hline $\begin{array}{l}10-40 \% \text { decreasers } \\
\text { and } \geq 30 \% \text { increasers }\end{array}$ & $\begin{array}{l}>3 \% \text { mainly } \\
\text { perennials }\end{array}$ & $3-10 \%$ mainly of grasses & $\begin{array}{l}4 \\
\text { seedlings }\end{array}$ & $\begin{array}{l}\text { Two size category } \\
\text { present }\end{array}$ & Slight sand mulch & Isolated capping & 4 \\
\hline $\begin{array}{l}10-40 \% \text { decreasers } \\
\text { and }<30 \% \text { increasers }\end{array}$ & $\begin{array}{l}>3 \% \text { mainly } \\
\text { of annuals }\end{array}$ & & $\begin{array}{l}3 \\
\text { seedlings }\end{array}$ & Present only old & $\begin{array}{l}\text { Slope side pedestals } \\
\text { (> 50\% capping) }\end{array}$ & > 50\% capping & 3 \\
\hline $\begin{array}{l}<10 \% \text { decreasers } \\
\text { and } \geq 50 \% \text { increasers }\end{array}$ & $\begin{array}{l}1-3 \% \text { basal } \\
\text { cover }\end{array}$ & $\begin{array}{l}3-10 \% \text { weeds or tree } \\
\text { leaves }\end{array}$ & $\begin{array}{l}2 \\
\text { seedlings }\end{array}$ & Only medium & $\begin{array}{l}\text { Steep-sided pedestals } \\
\text { (> 75\% capping) }\end{array}$ & > 75\% capping & 2 \\
\hline $\begin{array}{l}<10 \% \text { decreasers } \\
\text { and }<50 \% \text { increasers }\end{array}$ & $\begin{array}{l}<1 \% \text { basal } \\
\text { cover }\end{array}$ & & $\begin{array}{l}1 \\
\text { seedling }\end{array}$ & Only young & $\begin{array}{l}\text { Pedestals (almost } \\
100 \text { capping) }\end{array}$ & $\begin{array}{l}\text { Almost } 100 \% \\
\text { capping }\end{array}$ & 1 \\
\hline Bare ground & $0 \%$ & $<3 \%$ cover & $\begin{array}{l}\text { No } \\
\text { seedling }\end{array}$ & & Gullies & & 0 \\
\hline
\end{tabular}

GC grass composition, $B C$ basal cover, $L C$ litter cover, NS number of seedlings, $A G$ age distribution, $S C$ soil compaction, and $S E$ soil erosion 


\section{Acknowledgements}

The authors gratefully acknowledge the financial support received from the Federal Democratic Republic of Ethiopian, Ministry of Education for the research work. The authors further thank Mr. Bedru Roba from Adami-Tulu Research Center for his help in the identification of herbaceous species in the field and School of Animal and Range Sciences of Hawassa University for the analysis of nutritional content of grass samples. The authors also recognize the cooperation of Chagni cattle breed and conservation Ranch during the research work.

\section{Funding}

This research work was funded by the Federal Democratic Republic of Ethiopian, Ministry of Education. Funding bodies have no role in the design of the study and data collection, analysis, and interpretation of data and writing of the manuscript.

\section{Availability of data and materials}

Data for this manuscript was collected through field vegetation sampling and observation in the field.

\section{Authors' contributions}

YM conducted the field research, analyzed the data, and drafted the manuscript. AAn and AAb initiated the idea of the research, designed and interpreted the results, and fully participated in the whole process of the write-up of the manuscript. All authors revised the manuscript and read and approved the final version.

\section{Authors' information}

Yaregal Melak is an MSc student at Hawassa University. His research interest includes rangeland condition, plant species composition and nutritional content of forage plants. Hawassa University, College of Agriculture, Department of Animal and Range Sciences P.O.Box 05, Hawassa, Ethiopia. Ayana Angassa is a Rangeland Ecologists at Botswana University of Agriculture and Natural Resources. His research interest includes influence of grazing and climate on grassland ecosystems, carbon sequestration, indigenous knowledge, invasive plant species, and sustainable management and conservation of natural resources. Private Bag 0027, Sebele, Gaborone, Botswana. Aster Abebe is an Animal Nutritionist at Hawassa University. Her research interest includes the nutritional content of forage plants, grazing effects, indigenous knowledge, invasive plant species, and sustainable management and conservation of natural resources.

\section{Ethics approval and consent to participate}

Not applicable.

\section{Consent for publication}

Not applicable.

\section{Competing interests}

The authors declare that they have no competing interests.

\section{Publisher's Note}

Springer Nature remains neutral with regard to jurisdictional claims in published maps and institutional affiliations.

\section{Author details \\ ${ }^{1}$ Department of Animal and Range Sciences, Hawassa University, Awasa, Ethiopia. ${ }^{2}$ Department of Range and Forest Resources, Faculty of Natural bag 0027, Gaborone, Botswana. \\ Received: 25 October 2018 Accepted: 26 February 2019 \\ Published online: 31 March 2019} Resources, Botswana University of Agriculture and Natural Resources, Private

\section{References}

Abate T, Ebro A, Nigatu L (2012) Evaluation of rangeland in arid and semi-arid grazing land of Southeast Ethiopia. Int J Agric Sci 2:7

Abdel M, El hag MA, Bushara I, El-Hag FMA, Jadalla JB (2013) Effect of rangeland protection on nutritive value for range grazing small ruminants, North Kordofan, Sudan. Wudpecker J Agric Res 2(3):86-90
Allen VG, Batello C, Berretta EJ, Arzani H, Basiri M, Khatibi F, Chorbni G (2006) Nutritive value of some Zagros Mountain rangeland species. Small Rumin Res 65:128-135

Allen VG, Batello C, Berretta EJ, Hodgson J, Kothmann M, Li X, Mclvor J, Milne J, Morris C, Peeters A, Sanderson M (2010) An international terminology for grazing lands and grazing animals. Grass Forage Sci 66:2-28

Angassa A (2007) The dynamics of savanna ecosystems and management in Borana, Southern Ethiopia. PhD Thesis. Norwegian University of Life Sciences, Aas, p 180

Angassa A (2014) Effects of grazing intensity and bush encroachment on herbaceous specie and rangeland condition in southern Ethiopia. Land Degrad Dev 25:438-451

Angassa A, Baars RMT (2000). Ecological condition of encroached and nonencroached rangelands in Borana, Ethiopia. Afr J Ecol. 38(4):321-328.

Angassa A, Beyene F (2003) Current range condition in southern Ethiopia in relation to traditional management strategies: the perceptions of Borana pastoralists. Trop Grassl 37:53-59

Angassa A, Oba G (2008) Herder perceptions on impacts of range enclosures, crop farming, fire ban and bush encroachment on the rangelands of Borana, Southern Ethiopia. Hum Ecol 36(2):201-215

Angassa A, Oba G, Treydte AC, Weladji RB (2010) Role of traditional enclosures on the diversity of herbaceous vegetation in semi-arid rangelands, southern Ethiopia. Livest Res Rural Dev 22(9) Article \#163. Retrieved February 15, 2019, from http://www.lırd.org/lrrd22/9/anga22163.htm

Angassa A, Tolera A, Belayneh A (2006) The effects of physical environment on the condition of rangelands in Borana. Tropical Grasslands 40(1):33.

Asheber T, Kassahun A, Nigatu L, Kidane G/meskel (2010) Plant species composition, spatial distribution and diversity along a grazing gradient from livestock watering point in Allaidege rangeland of North-Eastern Ethiopia rangelands. J Dry Lands 3(2):226-233

Baars RMT, Chileshe EC, Kalokoni DR (1997) Technical notes: range condition in high cattle density areas in the Western province of Zambia. Trop Grassl 31:569-573

Bedeke W, Nigatu L (2015) Assessment of vegetation composition and productivity of rangeland as affected by altitude and grazing pressure in Kuraz District of South Omo Zone, South Western Ethiopia. J Biol Agric Healthcare 5(23):113-124

Bilatu A, Binyam K, Solomon Z, Eskinder A, Ferede A (2013) Forage yield and nutritive value of natural pastures at varying levels of maturity in north west lowlands of Ethiopia. World J Agric Sci 1(3):106-112

Canan T, Ilker N, Murat A (2011) Impact of watering points on vegetation changes of a semi-arid natural pasture in Tekirdag Province, Turkey. Afr J Agric Res 6(4):896-900

Carlier L, Rotar L, Vlahova M, Vidican R (2009) Importance and functions of grasslands. Not Bot Hort Agrobot Cluj 37(1):25-30

Chape S, Harrison J, Spalding M, Lysenko I (2005) Measuring the extent and effectiveness of protected areas as an indicator for meeting global biodiversity targets. Philos Trans R Soc 360:443-455

Denbeshu D, Angassa A, Abebe A, Burka A and Tolera A. (2018) Human-climate induced drivers of mountain grassland over the last 40 years in Sidama, Ethiopia: perceptions versus empirical evidence. Ecol Processes 7:34 https:// doi.org/10.1186/s13717-018-0145-5.

Dyksterhuis EJ (1949) Condition and management of rangelands based on qualitative ecology. J Range Manage 2:104-112

Eldridge DJ, Delgado-Baquerizo M (2017) Continental-scale impacts of livestock grazing on ecosystem supporting and regulating services. Land Degrad Dev 28:1473-1481

Eldridge DJ, Whitford WG (2009) Soil disturbance by native animals along grazing gradients in arid grassland. J Arid Environ 73:1144-1148

Emmanuel Z, Geoffrey K, Charles G, Swidiq M, Denis M (2012) Production systems, land cover change and soil factors affecting pasture production in semi-arid Nakasongola. Int J Agron Agric Res 2(5):1-12

Fromann B, Persson S (1974) An illustrated guide to the grasses of Ethiopia. CADU (Chillalo Agricultural Development Unit), Assela

Galal A, Fashir K, Elkheir MS, Mohammed IA (2016) The impacts of high grazing pressure on plants species diversity with focusing on native forbs species case study of Dilling Locality - South Kordofan State- Sudan. Int J Innov Sci Eng Technol 3:328-339

Habtamu TK, Madakadze IC, Angassa A, Hassen A (2013) Nutritive value of grasses in semi-arid rangelands of Ethiopia: local experience based herbage preference evaluation versus laboratory analysis. Asian-Aust J Anim Sci 26(3):366-377 
Harrington R (2002) The effects of artificial watering points on the distribution and abundance of avifauna in an arid and semi-arid Mallee environment. PhD thesis, Department of Zoology, The University of Melbourne

Ivy P (1969) Veld condition assessments. In: Proceedings of Veld Management Conference, Bulawayo, pp 105-111, 27-31 May 1969

Landsberg J, James CD, Maconochie J, Nicholls AO, Stol J, Tynan R (2002) Scalerelated effects of grazing on native plant communities in an arid rangeland region of South Australia. J Appl Ecol 39:427-444

Lange RT (1969) The Piosphere: sheep track and dung patters. J Range Manag 22:396-400

Martin SO (2006) The impact of water points on spatial distribution of vegetation range condition and soil properties in mbirikani group ranch, Kajiado district, Kenya. (thesis). Addis Ababa University, Addis Ababa, p 50

Melak Y (2017) Effects of distance from water points on grassland condition, biomass production and nutritional quality of grasses in Chagni ranch, North West Ethiopia. MSc. Thesis. Hawassa University, Hawassa

Menale M, Mekuriaw Z, Mekuriaw G, Taye M (2011) Reproductive performances of fogera cattle at metekel cattle breeding and multiplication ranch, North West Ethiopia

Mengistu A, Angassa A, Abebe A (2015) The effects of area enclosures on rangeland condition, herbaceous biomass and nutritional quality in Southeast Ethiopia. Sci Technol Arts Res J 4(2):79-88

Messerli B, Ives JD (eds) (1997) Mountains of the world: a global priority. Parthenon, New York.

Mills AJ, Rogers KH, Stalmans M, Witkowski ETF (2006) A framework for exploring the determinants of savanna and grassland distribution. Bioscience 56:579589

Newmark WD (2008) Isolation of African protected areas. Front Ecol Environ 6: $321-328$

Oba G, Post E, Syvertsen PO, Stenseth NC (2000) Bush cover and range condition assessments in relation to landscape and grazing in southern Ethiopia. Landsc Ecol 15:535-546

Paul AL, Eubanks MD, Behmer ST (2015) Water stress in grasslands: dynamic responses of plants and insect herbivores. Oikos 124:381-390

Peris K (2004) Forage diversity and impact of grazing management on rangeland ecosystems in Mbeere District, Kenya. (LUCID) land use change analysis as an approach for investigating biodiversity loss and land degradation project

Reid RS, Nyabenge M, Hanson J (2005) The changing face of pastoral systems in grass -dominated ecosystems of Eastern Africa. Chapter 2. In: Grassland of the world. Plant Production and Protection Series No. 34

Shahriary MWP, Tongway DJ, Azarnivand H, Jafari M, Mohseni Saravi M (2012) Plant species composition and soil characteristics around Iranian piospheres. J Arid Environ 82:106-114

Solomon T, Snyman HA, Smit GN (2007) Rangeland dynamics in southern Ethiopia: (1) botanical composition of grasses and soil characteristics in relation to land-use and distance from water in semi-arid Borana rangelands. J Environ Manag 85:429-442

Solomon TB, Mlisa L, Gxasheka M (2014) Local perceptions of livestock husbandry and rangeland degradation in the highlands of South Africa: implication for development interventions. J Hum Ecol 47(3):257-268

Stypinski P (2011) The effect of grassland-based forages on milk quality and quantity. Agron Res 9 (Special Issue II):479-488

Tadesse A, Solomon A (2014) Assessment of grazing land and livestock feed balance in Gummara-Rib Watershed, Ethiopia. Curr Agric Res J 2(2):114-122

Tainton NM (1981) The assessment of veld condition. In: Tainton NM (ed) Veld and pasture management in South Africa. Shuter and Shooter Ltd, Pietermaritzburg

Temesgen G, Aleme A, Mulata H (2014) Climate change and livestock production in Ethiopia. Acad J Environ Sci 2(4):59-62

Todd SW (2006) Gradients in vegetation cover, structure and species richness of Nama-Karoo shrub lands in relation to distance from livestock watering points. J Appl Ecol 43:293-304

Van Soest PJ, Robertson JB (1985) Analysis of forages and fibrous feeds. In: Laboratory Manual for Animal Science 613. Cornell University, Ithaca, p 202

\section{Submit your manuscript to a SpringerOpen ${ }^{\circ}$ journal and benefit from:}

- Convenient online submission

- Rigorous peer review

- Open access: articles freely available online

- High visibility within the field

- Retaining the copyright to your article

Submit your next manuscript at $\boldsymbol{\nabla}$ springeropen.com 